\title{
Montana Department of Agriculture
}

Agricultural Sciences Division

Technical Services Bureau

Helena, Montana 59620

\section{A FIELD EVALUATION OF ZINC PHOSPHIDE OAT BAIT FOR CONTROLLING BLACK-TAILED PRAIRIE DOGS AND RICHARDSON AND COLUMBIAN GROUND SQUIRRELS}

by

Monty Sullins and Daniel Sullivan

\author{
STATE DOCUMENTS COLLECTION \\ FEB ?" 1997 \\ MONTANA STATE LIBRARY \\ 1515 E. 6th AVE. \\ HELENA, MONTANA 59520
}

\begin{abstract}
Field trials were conducted to determine the efficacy of zinc phosphide oat baits as a control for black-tailed prairie dogs (Cynomys ludovicianus) and Richardson (Spermophilus richardsoni) and Columbian (Spermophilus columbianus) ground squirrels in Montana. Efficacy was compared when zinc phosphide oat bait was applied with and without an application of nontoxic oats as prebait. Zinc phosphide efficacy was greater than 90 percent on the prairie dog and Richardson ground squirrel with prebaiting. Efficacy without prebaiting was not judged acceptable. Trials with and without the use of prebait prior to application of zinc phosphide oat bait for control of the Columbian ground squirrel was not found to be efficacious.
\end{abstract}

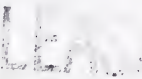

Technical Report 95-02

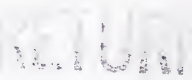

July 1995 
0

,

○

,

ง 。 
-

0

O 
0

○

。 


\section{INTRODUCTION}

The U.S. Environmental Protection Agency has canceled the previously and widely used field rodenticides sodium monofluoroacetate (Compound 1080) and strychnine for above ground uses. In Montana, only two rodenticides formulated on grain baits continue to be registered that are economical for large acreage application, zinc phosphide and chlorphacinone. Zinc phosphide has been registered as a field rodenticide since the 1940 's and has been available in Montana to control prairie dogs and ground squirrels. Zinc phosphide baits have a long history of poor acceptance and erratic efficacy. Prebaiting zinc phosphide baits with clean, nontoxic oats has been a long recommended practice to increase efficacy, but this significantly increases labor and cost in its use. As a result, zinc phosphide baits have had poor acceptance among users of field rodenticides and has not been widely used in Montana.

HACCO, Inc. is currently marketing a zinc phosphide bait that is formulated on dehulled, rolled oats that have been baked to a temperature of $400^{\circ} \mathrm{F}$. The baking process prevents germination of the oats and other unwanted seeds that may contaminate the bait. The cooking alters the flavor of the oats, reportedly increasing acceptance and eliminating or reducing the need to prebait before application.

The field trials reported on in this study were conducted to test this claim.

\section{OBJECTIVES}

The objectives were to compare the efficacy of prebaited and non-prebaited applications of Hacco roasted oat zinc phosphide grain bait on the black-tailed prairie dog and the Richardson and Columbian ground squirrels.

\section{STUDY AREAS}

Prairie Dog:

Study plots were established on rangeland pasture located near Molt approximately 25 miles northwest of Billings, Montana. The field trial was conducted April 1 - 7, 1995.

Richardson Ground Squirrel:

Study plots were established in dryland, grass hayfields near Sheridan and Wilsall, Montana. The field trial at Sheridan was conducted April 13-23,1995 The field trial at Wilsall was conducted April 19 - May 5, 1995.

Columbian Ground Squirrel:

Study plots were established in grass hayfields near Deer Lodge, Montana and field trials were conducted May 11 - 26, 1995. 
Vegetation on each of the study sites had broken dormancy and was growing resulting in an abundance of green vegetation present at each site. The prairie dogs and ground squirrels were actively foraging on the growing vegetation. No seed production was occurring at any site which provided no predisposition for the prairie dogs or ground squirrels to forage on grains.

\section{METHODS}

Treatment plots and one control plot was established at each study site. A buffer area, surrounding each baited plot, large enough to prevent immediate immigration of the test rodents onto the study plot, was established. The number of test plots established varied at each site. At minimum at each site was: 1.) a treatment plot prebaited with clean, nontoxic roasted oats two days prior to application of HACCO zinc phosphide oat bait ( $2 \%$ active ingredient); 2.) a second plot treated with the zinc phosphide oat bait only and; 3.) a control plot that was not baited. Bait and prebait were scattered on bare or sparsely vegetated ground on the surface near each burrow entrance within each plot and its associated buffer area. Prebait and bait were applied by hand using calibrated dippers to apply one teaspoon ( 5 grams) of bait per burrow opening.

Prior to application of any bait at the study sites, bait acceptance test were conducted at each study site. Bait acceptance tests were conducted by flagging 20 to 30 burrows spaced at least 25 feet apart. One teaspoon of nontoxic oats was scattered in a 6 inch bait spot by each marked burrow. Consumption of the bait was checked after two days. Bait consumption of less than 80 percent would result in postponement of bait application until additional bait acceptance tests at different burrows resulted in acceptance of bait exceeding 80 percent within two days of placement.

Prairie dog and ground squirrel activity was monitored at each site and on all plots by visual counts using binoculars. Three counts were made from the same point at each plot on each of two to three days before and after treatment. The highest number of each of the pretreatment and posttreatment counts provided average pretreatment and posttreatment activity indices (AI). Percent reduction in activity for each plot was calculated using the formula:

$$
\text { Percent Reduction }=\frac{\text { Pretreatment AI - Posttreatment AI }}{\text { Pretreatment AI }} \times 100
$$

Amount of bait applied and time required for application was recorded for each plot.

\section{RESULTS}

\section{Prairie Dog:}

Percent reduction in prairie dog activity on two plots that were prebaited was 90.5 percent and 94.4 percent. This compares to 65.2 percent and 88.2 percent reduction in activity on two plots that were not prebaited (Table 1). 
Table 1. Efficacy of zinc phosphide oat bait for control of black-tailed prairie dog and Columbian and Richardson ground squirrels.

\begin{tabular}{|c|c|c|c|c|c|}
\hline Species & Date & Treatment & $\begin{array}{c}\% \\
\text { Change }\end{array}$ & $\begin{array}{l}\text { Man } \\
\text { Hours }\end{array}$ & $\begin{array}{l}\text { Lbs. Bait } \\
\text { Used }\end{array}$ \\
\hline \multicolumn{6}{|c|}{ Billings Area } \\
\hline Prairie Dog & $4 / 5 / 95$ & w/ prebait & -94.4 & 3 & 6 \\
\hline Prairie Dog & $4 / 5 / 95$ & w/ prebait & -90.5 & 3.6 & 8 \\
\hline Prairie Dog & $4 / 5 / 95$ & w/o prebait & -88.2 & 2.5 & 17.25 \\
\hline Prairie Dog & $4 / 5 / 95$ & w/o prebait & -65.2 & 1.5 & 7 \\
\hline Prairie Dog & $4 / 5 / 95$ & Control & +9.0 & - & - \\
\hline \multicolumn{6}{|c|}{ Sheridan Area } \\
\hline Richardson Gd Sq & $4 / 21 / 95$ & w/ prebait & -96.3 & 7 & 9 \\
\hline Richardson Gd Sq & $4 / 21 / 95$ & w/o prebait & -63.0 & 12 & 29 \\
\hline Richardson Gd Sq & 4/21/95 & Control & -2.5 & - & - \\
\hline \multicolumn{6}{|c|}{ Wilsall Area } \\
\hline Richardson Gd Sq & $5 / 1 / 95$ & w/ prebait & -95.6 & 8 & 24 \\
\hline Richardson $\mathrm{Gd} \mathrm{Sq}$ & $5 / 1 / 95$ & w/o prebait & -59.3 & 6 & 11 \\
\hline Richardson Gd Sq & $5 / 1 / 95$ & Control & -3.9 & - & - \\
\hline \multicolumn{6}{|c|}{ Deer Lodge } \\
\hline Columbian $\mathrm{Gd} \mathrm{Sq}$ & $5 / 19 / 95$ & w/prebait & -58.4 & 4.5 & 12 \\
\hline Columbian Gd Sq & $5 / 19 / 95$ & w/prebait & -48.1 & 6 & 10 \\
\hline Columbian $\mathrm{Gd} \mathrm{Sq}$ & $5 / 19 / 95$ & w/o prebait & -13.0 & 1.8 & 9 \\
\hline Columbian $\mathrm{Gd} \mathrm{Sq}$ & $5 / 19 / 95$ & Control & +5.0 & - & - \\
\hline
\end{tabular}

Richardson Ground Squirrel:

Percent reduction in squirrel activity at two sites that were prebaited was 96.3 percent (Sheridan) and 95.6 percent (Wilsall). Zinc phosphide applied without prebait resulted in a reduction in squirrel activity of 63.0 percent (Sheridan) and 59.3 percent (Wilsall). 


\section{Columbian Ground Squirrel:}

Percent reduction in squirrel activity on two plots that were prebaited at the Deer Lodge study site was 48.1 percent and 58.4 percent. This compares to a 13.0 percent reduction in activity on one plot that was not prebaited.

\section{Control Plots - All Sites:}

Prairie dog and ground squirrel activity did not significantly change on any of the control plots during the study periods.

Heavy rain occurred at the prairie dog study site 18 hours after bait application. Actual time that the bait was available to the prairie dogs during their active hours prior to the rainfall was about 6 to 8 hours. No significant rain occurred on any of the ground squirrel study sites within three days after application of the zinc phosphide oat bait.

\section{DISCUSSION}

Previous studies (Sullins and Sullivan, 1990; Sullins, 1980) have shown that zinc phosphide grain baits can obtain 90 percent and greater efficacy on prairie dogs and Richardson ground squirrels when applied with prebait and in the absence of green vegetation. These studies have also shown that zinc phosphide grain bait application for control of prairie dogs and Richardson ground squirrels when green vegetation is present is often less than 70 percent control. Because of the Columbian ground squirrel's hibernation biology, it is seldom active when green vegetation is not present. Efficacy trials with zinc phosphide on the Columbian have been consistently ineffective.

The results of the efficacy trials conducted with HACCO zinc phosphide oat bait when prebait was applied resulted in greater than 90 percent control of prairie dog and Richardson ground squirrel in the presence of green vegetation. This level of efficacy is generally considered excellent when controlling these species to reduce agricultural crop damage below economic thresholds.

These results, based on the limited number of replications conduct in this study, show that this bait can be efficacious in the presence of green vegetation with the application of prebait for control of prairie dogs and Richardson ground squirrels. These trials were conducted in the presence of green vegetation, but before there was substantial growth. Bait application during late May, June and early July when there is significantly more vegetation may be less efficacious. The results in the Richardson ground squirrel trials indicate fairly dramatically that application of prebait is necessary for acceptable results.

The results in the prairie dog trials where prebait was not applied are difficult to interpret but are consistent with the erratic nature of zinc phosphide illustrated by other studies. Rangeland sites are generally less lush than crop areas perhaps providing less competition with the bait which may improve efficacy. This probably depends on varying vegetation characteristics of each site. It is unknown what effect the rain so soon after 
treatment may have had on efficacy at the prairie dog study site.

The trials conducted on the Columbian ground squirrel did not show acceptable efficacy. This illustrates that each species, despite how similar they may appear, are unique and must be studied separately.

One hallmark of a good pesticide is that when applied according to label directions it will achieve good results consistently. We believe that prebaiting and careful timing of the bait application will be very important in obtaining consistent and efficacious results in most situations, particularly if green vegetation is present. Users who short cut procedures by not prebaiting or who delay bait application to later in the season are likely to experience erratic and less than efficacious results. Additionally, there seems to be certain unquantifiable variables, both biological or environmental, that decrease the efficacy of zinc phosphide and that are beyond the user's control.

\section{RECOMMENDATIONS}

1. Zinc phosphide oat bait applied when green vegetation is present should be prebaited.

2. Bait application should be conducted early in the season when controlling the Richardson ground squirrel but only after the entire population of squirrels in the control area have emerged from hibernation.

3. A determination if this bait can be effective without application of prebait when green vegetation is not present is needed. Anecdotal reports for the prairie dog and Richardson ground squirrel indicate that good results are obtained when the bait is used in dry conditions with little or no green vegetation present without prebaiting. We had hoped to test use in these conditions this year but persistent snow and rain during early spring prevented getting into the field sooner.

4. These trials do not provide information to determine if the cooked oats used in the formulation of this bait results in better acceptance that the same oats left uncooked. It would be useful to determine if cooking the oats is a critical factor in the efficacy of this bait. This could be done by testing efficacy of bait formulated with cooked oats against bait formulated with uncooked oats. Although cooking also has an important functions in stopping seed germination, this knowledge could have important applications in the formulation of other rodenticide baits.

5. Use of this product or other zinc phosphide baits is not recommended for used in control of the Columbian ground squirrel if green vegetation is present.

Landowner using zinc phosphide bait on the Columbian should be advised to make application in arid sites or after crops have been harvested and the stubble is dry or in the case of forage crops, before regrowth occurs. 


\section{ACKNOWLEDGEMENTS}

We thank landowners Lee Lane (Molt), Melvin Goeffna (Wilsall), Chris Koonce - Cal Creek Ranch (Sheridan), Joe Launderville - Grant-Kohrs Ranch NPS (Deer Lodge) for used of their properties. Max Merenz, Melvin Goeffna and staff of Cal Creek Ranch and Grant-Kohrs Ranch assisted with bait application. HACCO, Inc. provided the zinc phosphide oat bait and financial assistance for travel and per diem expenses.

\section{LITERATURE CITED}

Sullins, M. and Sullivan, D. 1991. A field evaluation of zinc phosphide baits for controlling Richardson and Columbian ground squirrels. Montana Department of Agriculture, Technical Report 91-01. 7 pp.

Sullins, M. 1980. Efficacy of strychnine and zinc phosphide baits for controlling Black-tailed Prairie Dogs. Montana Department of Livestock Report. 3 pp.

00172 lvert $\backslash$ tr9502.dds 